\begin{tabular}{|c|c|}
\hline \multirow{3}{*}{ 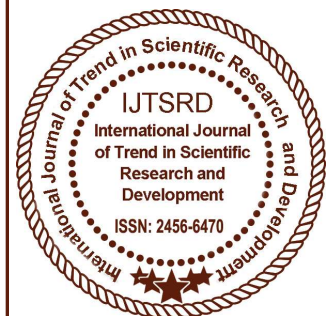 } & $\begin{array}{l}\text { International Journal of Trend in Scientific } \\
\text { Research and Development (IJTSRD) }\end{array}$ \\
\hline & International Open Access Journal \\
\hline & ISSN No: 2456 - 6470 | www.ijtsrd.com | Volume - 2 | Issue - 5 \\
\hline
\end{tabular}

\title{
A Study on Impact of Entrepreneurial Characteristics on Success of Business
}

\author{
Ms. Kruti Bhatt, Ms. Peenal Sankhla \\ Lecturer, Department of Management, UkaTarsadia, University, \\ Maliba Campus, Tarsadi, Surat, Gujarat, India
}

\begin{abstract}
Entrepreneur is a person who takes risks, accepts challenges, raise fund and starts the business. The main aim of the study is to identify the entrepreneurial characteristics which have major impact on success of business. 50 entrepreneurs were taken as sample size to collect data. Chi square analysis is used as data analysis technique. Risk taking ability, good communication skill and self-confidence of an entrepreneur are the major characteristics which have impact on success of business.
\end{abstract}

Keywords: Entrepreneurial characteristics, Success, Business

\section{INTRODUCTION}

\section{Characteristics of Entrepreneurs:}

Risk Taking

The main characteristic that makes individual an entrepreneur is ability to cope up with the future uncertainty. If entrepreneur is able to deal with all the uncertain situation then it will drive their business towards the path of success.

\section{Hard work \& Disciplined Dedication}

The success of business highly depends on the ability to work hard and dedication towards the work that entrepreneurs do. The commitment and dedication towards business operation give reputation to business in market place and can result into sustainable development of business.

\section{Adaptability \& Flexibility}

The best quality of entrepreneur is to be passionate for what they do. The dynamic nature of entrepreneurs allows them to cope up with changing needs of client, market and protect their business from the failure. The market place is full of uncertainty and adaptation of challenges is the only solution to be a successful business person.

\section{Planning}

Planning is predetermined course of future action. As an entrepreneur it is required to plan everything in advance to meet future uncertainty and to reduce the risk of failure in business.

\section{Money Management}

Any business can get profit after some time of operation so till then it is required to make wise utilization of available fund. Successful entrepreneurs make decision with respect to meet present and future obligations regarding money for the smoother conduct of business.

\section{Being Prepared to Take the Exit}

All business ideas cannot be converted into success. Entrepreneurs have to keep one thought in mind with reference to take exit from industry as an when required. It is better to shut down the sick unit and think about some other profitable venture.

\section{LITERATURE REVIEW}

Elvis Mynyaradzi Ganiyaupfu (2013) The Entrepreneur and Firm Characteristics Affecting Success of Small and Medium Enterprises (SMEs) in Gauteng Province. The main aim of the research was to analyse distinct effects of entrepreneur and firm characteristics on success of SMEs. The tool used to analyse the result was correlation. The researcher had collected the data by using the primary 
method. The major findings of this study was entrepreneur and firm characteristics have statistically significant positive effects on success of SMEs in Gauteng province imply that small and medium size enterprises should improve their educational qualifications and managerial competences in the areas of their respective business operations.

Md. Aminul Islam, Mohammad Aktaruzzaman Khan (2013) The Effect of Entrepreneur and Firm Characteristics on the Business Success of Small and Medium Enterprises (SMEs). The main aim of the research was to analysis Effect of Entrepreneur and Firm Characteristics on success in small business in Bangladesh. . The researcher had collected the data by using the primary method. Data are analysed using statistical package for social sciences (SPSS). The tool used to analysis the result of independent sample t-test shows that gender plays a significant role on business. This study has implications for entrepreneurs and policy makers.

Doris Gomezelj Omerzel (2016) The Impact of Entrepreneurial Characteristics and Organizational Culture on Innovativeness in Tourism Firms. The main aim is Entrepreneurial characteristics and organizational culture has an impaction the innovative capability of a company. The tool used to analysis the result was correlation matrix. The researcher tries to examine the influence of different individual entrepreneurial characteristics and organizational culture dimensions. The researcher had collected the data by using the primary method. Result aim the aim of composing new variables, a factor analysis was performed. This study was to identify entrepreneurial orientation and organizational culture effects on service innovation in companies.

Murad Husni Abdul wahab \& Dr. Rula Ali AlDamen. (2015) The Impact of Entrepreneurs' Characteristics on Small Business Success at Medical Instruments Supplies Organizations in Jordan. This study is aimed to investigate the impact of the entrepreneurs' characteristics on small business success at Medical Instruments Supplies Organizations in Jordan. The researcher had collected the data by using the second method. The tool used to analysis the Statistical techniques such as descriptive statistics, t-test, ANOVA test, correlation, multiple regressions employed to test the hypotheses. The entrepreneurs' characteristics do not have an impact on small business success at Medical
Instruments Supplies Organizations in Jordan, at statistical significance.

Kamalakumati Karunanithy \& Sathiyakala Jeyaraman (2013) The Impact of Entrepreneurial Characteristics on the Organizational Development of the Small Business Entrepreneurs. The main objective for the study is to assess how the characteristics influence the organizational development. The researcher the data was collected from Primary as well as secondary sources. The tool used to analysis the Regression and correlation analysis was done to find out the contribution of each variable \& correlation analysis showed that the characteristics of the small business entrepreneurs.

Gloria Mothibi (2015) The effect of entrepreneurial and firm characteristics on performance of small and medium enterprises in Pretoria. The research objective is to analyze effects of entrepreneur and firm characteristics on performance of SMEs. The primary aim of this study was to analyze the effects of entrepreneur and firm characteristics on performance of small and medium enterprises (SMEs) in Pretoria. The data were sought and analyzed using SPSS statistical. The tool used to multiple regression analysis using the ordinary least squares regression. Research was to investigate the effects of entrepreneur characteristics and firm characteristics on performance of small and medium size enterprises in Pretoria district.

S. a, ilori, m. o. ire fin abereijo, i.o aderemi, h. o. s (2006) Evaluation of the impact of Entrepreneurial characteristics on the performance of small scale manufacturing industries in Nigeria. The main aim of research study evaluated the impact of entrepreneurial characteristics on the performance of small-scale manufacturing industries in Nigeria. The researcher had collected the data by using the primary method. The tool used to study the result was correlation analysis and Regression analysis with descriptive and inferential statistics with the aid of Statistical packages for social scientists (SPSS). The study concluded that the negative attributes exhibited by the Respondents in most of the PEC were critical factors in the dismal performance of the small-scale manufacturing industries, which need to be developed in the entrepreneurs through training.

Mallaye, D., Yogo, T. U., \& Blandine, N. G. K (2003) Characteristics of Entrepreneurs and 
Performance of Micro, Small and Medium Enterprises in Post conflict State: Evidence from Chad. This study aims at assessing the relationship between the profile of entrepreneurs and the performance of SMEs in Chad. The researcher had collected the data by using the primary method. The tool used to analyse the result was correlation. The main objective of this study is to assess the effects of the characteristics of entrepreneurs on the SMEs performance in Chad. The researcher had collected the data by using the primary method. This study is policy relevant for at least two reasons. First, the widespread of informality in Africa in general and in Chad in particular is often seen as the source of low paid jobs and working poverty.

\section{Juuli Chavez (2016) The Personality} Characteristics of an Entrepreneur and their Effects on the Performance of a New Business Venture. The aim is to explain how the personality characteristics of an entrepreneur differ from those of a non entrepreneur. The researcher had collected the data by using the primary method. The aims to study the different personality characteristics of the entrepreneur and to find the connection between these characteristics and how they are linked to the performance of a new business venture.
Descriptive research design is used for study. Questionnaires were given to 50 entrepreneurs of Navsari. Both Primary and secondary data were collected. The researcher has taken profitability as the parameter to measure success. Non probability convenience sampling was used. Chi square analysis is used as statistical tool.

\section{DATA ANALYSIS}

Chi-Square Tests (Profitability at start-up * Characteristics of an Entrepreneur)

$\mathrm{H} 0$ : There is no association between Profitability of business at start-up and characteristics of an Entrepreneur.

$\mathrm{H}_{1}$ : There is association between Profitability of business at start-up and characteristics of an Entrepreneur.

\section{Chi-Square Tests (Profitability at present * Characteristics of an Entrepreneur)}

$\mathrm{H}_{0}$ : There is no association between Profitability of business at present and characteristics of an

Entrepreneur.

$\mathrm{H}_{1}$ : There is association between Profitability of business at present and characteristics of an Entrepreneur.

\section{RESEARCH METHODOLOGY:}

Research Objective:

$>$ To identify the entrepreneurial characteristics having major impact on success of business.

\begin{tabular}{|l|l|l|l|l|}
\hline \multicolumn{1}{|c|}{ Characteristics } & $\begin{array}{c}\text { Value (At } \\
\text { Start-up) }\end{array}$ & $\begin{array}{l}\text { Asymp. Sig. (2-sided } \\
\text { (At Start-up) }\end{array}$ & $\begin{array}{c}\text { Value (At } \\
\text { present) }\end{array}$ & $\begin{array}{c}\text { Asymp. Sig. (2-sided } \\
\text { (At present) }\end{array}$ \\
\hline Openness to accept new ideas & 4.922 & 0.085 & 10.406 & 0.015 \\
\hline Ability to take risk & 30.269 & 0.000 & 15.831 & 0.015 \\
\hline $\begin{array}{l}\text { Committed towards } \\
\text { achievement of goal }\end{array}$ & 4.472 & 0.346 & 17.445 & 0.008 \\
\hline Acceptance of outcome & 19.904 & 0.000 & 5.630 & 0.131 \\
\hline Self Confidence & 20.129 & 0.000 & 26.063 & 0.000 \\
\hline Proper communication & 18.379 & 0.001 & 31.723 & 0.000 \\
\hline Recognition of employee & 13.234 & 0.010 & 19.322 & 0.004 \\
\hline $\begin{array}{l}\text { Willingness to scarifies } \\
\text { Personal priorities }\end{array}$ & 3.010 & 0.556 & 22.784 & 0.001 \\
\hline Persistent in problem solving & 20.378 & 0.000 & 27.448 & 0.000 \\
\hline Secure investment & 24.252 & 0.000 & 37.457 & 0.000 \\
\hline Disorganized decision & 2.184 & 0.702 & 8.444 & 0.207 \\
\hline Forecasting future deal & 16.624 & 0.002 & 31.831 & 0.000 \\
\hline $\begin{array}{l}\text { Positive response towards } \\
\text { uncertain situation }\end{array}$ & 8.068 & 0.089 & 24.787 & 0.000 \\
\hline Never give up attitude & 11.600 & 0.021 & 7.032 & 0.318 \\
\hline
\end{tabular}


International Journal of Trend in Scientific Research and Development (IJTSRD) ISSN: 2456-6470

\begin{tabular}{|l|l|l|l|l|}
\hline Goal achievement & 14.790 & 0.005 & 16.088 & 0.013 \\
\hline Participative management & 26.990 & 0.000 & 13.211 & 0.040 \\
\hline Adaption changes & 1.190 & 0.552 & 9.474 & 0.024 \\
\hline Creativity & 49.291 & 0.000 & 20.563 & 0.003 \\
\hline Anticipation of changes & 7.253 & 0.027 & 5.4671 & 0.141 \\
\hline Result oriented & 14.899 & 0.005 & 23.245 & 0.01 \\
\hline
\end{tabular}

\section{FINDINGS:}

$>$ Ability to take risk, self-confidence, proper communication, recognition of employee, persistent in problem solving, secure investment, forecasting for future deal, never give up attitude, goal achievement, participative management, creativity, anticipate changes, result oriented are the characteristics having impact on profitability of business.

$>$ Disorganized decision taken by entrepreneurs may create problem for business and have no direct association with profitability of business.

$>$ Anticipation of changes, acceptance of outcome, never give up attitude are the characteristics having no association with profitability of business at starting up the business while after establishment of business these characteristics have association with profitability of business.

$>$ Openness to accept new ideas, commitment towards goal achievement, willingness to sacrifice personal priorities, positive response towards uncertain situation, adaption of changes are the characteristics having no association with profitability of business at starting up of business. After establishment of business these characteristics have association with profitability of business.

\section{CONCLUSION:}

From the research, it is concluded that Risk taking ability, good communication skills, proper investment and good HR practices are entrepreneurial characteristics having major impact on success in business.

\section{BIBLIOGRAPHY:}

1. Ganyaupfu, E. M. (2013). Entrepreneur and Firm Characteristics Affecting Success of Small and Medium Enterprises (SMEs) in Gauteng Province.

2. Islam, M. A., Khan, M. A., Obaidullah, A. Z. M., \& Alam, M. S. (2011). Effect of entrepreneur and firm characteristics on the business success of small and medium enterprises (SMEs) in Bangladesh. International Journal of Business and Management, 6(3), 289.

3. Gomezelj Omerzel, D. (2016). The impact of entrepreneurial characteristics and organisational culture on innovativeness in tourism firms

4. Al-Damen, R. A. (2015). The impact of entrepreneurs' characteristics on small business success at medical instruments supplies organizations in Jordan. International Journal of Business and Social Science, 6 (8).

5. Karunanithy, K., \& Jeyaraman, S. (2013). Impact of entrepreneurial characteristics on the organizational development of the small business entrepreneurs. Industrial Engineering Letters, 3(6), 28-33.

6. Mothibi, G. (2015). The Effects of Entrepreneurial and Firm Characteristic on Performance of Small and Medium Enterprises in Pretoria. International Journal of Economics, Commerce and Management United Kingdom, 3(3), 1-8.

7. Adegbite, S. A., Ilori, M. O., Irefin, I. A., Abereijo, I. O., \& Aderemi, H. O. S. (2007). Evaluation of the impact of entrepreneurial characteristics on the performance of small scale manufacturing industries in Nigeria. Journal of Asia Entrepreneurship and sustainability, 3(1), 1.

8. Mallaye, D., Yogo, T. U., \& Blandine, N. G. K. Characteristics of Entrepreneurs and Performance of Micro, Small and Medium Enterprises in Post conflict State: Evidence from Chad.

9. Chavez, J. (2016). The personality characteristics of an entrepreneur and their effects on the performance of a new business venture.

10. www.wikipedia.com 